\title{
ISOLATION OF A COTTON NADP(H) OXIDASE HOMOLOGUE INDUCED BY DROUGHT STRESS ${ }^{1}$
}

\author{
ALEXANDRE LIMA NEPOMUCENO ${ }^{2}$, JAMES MCD STEWART ${ }^{3}$, DERRICK OOSTERHUIS ${ }^{4}$, RICKIE TURLEY ${ }^{5}$, \\ NORMAN NEUMAIER ${ }^{2}$ and JOSÉ RENATO BOUÇAS FARIAS ${ }^{2}$
}

\begin{abstract}
The aim of this study was to identify and isolate genes that are differentially expressed in four selected cotton (Gossypium hirsutum L.) genotypes contrasting according to their tolerance to water deficit. The genotypes studied were Siokra L-23, Stoneville 506, CS 50 and T-1521. Physiological, morphological and developmental changes that confer drought tolerance in plants must have a molecular genetic basis. To identify and isolate the genes, the mRNA Differential Display (DD) technique was used. Messenger RNAs differentially expressed during water deficit were identified, isolated, cloned and sequenced. The cloned transcript A12B15-5, a NADP $(\mathrm{H})$ oxidase homologue, was up regulated only during the water deficit stress and only in Siokra L-23, a drought tolerant genotype. Ribonuclease protection assay confirmed that transcription.
\end{abstract}

Index terms: messenger RNA, gene expression, genetic transformation, water deficit.

\author{
ISOLAMENTO DE UM cDNA EM ALGODÃO HOMÓLOGO A UMA NADP(H) OXIDASE \\ E INDUZIDO DURANTE A SECA
}

\begin{abstract}
RESUMO - O objetivo deste estudo foi identificar e isolar genes diferencialmente expressos em quatro genótipos de algodão (Gossypium hirsutum L.) que apresentam respostas distintas ao déficit hídrico. Os genótipos estudados foram Siokra L-23, Stoneville 506, CS 50 e T-1521. As mudanças fisiológicas, morfológicas e de desenvolvimento que as plantas apresentam para suportar a diminuição na disponibilidade de água tem, obrigatoriamente, uma base molecular genética. Utilizou-se a técnica de "Differential Display" para identificar e isolar os genes diferencialmente expressos. RNAs mensageiros diferencialmente expressos durante o déficit hídrico foram identificados, isolados, clonados e seqüenciados. O clone A12B15-5 apresentou homologia com uma NADP(H) oxidase e foi expresso somente durante o período de déficit hídrico em Siokra L-23, um genótipo de algodão tolerante à seca. O uso da técnica "Ribonuclease Protection Assay" confirmou essa expressão.
\end{abstract}

Termos para indexação: RNAmensageiro, expressão gênica, transformação genética, déficit hídrico

\section{INTRODUCTION}

When plants started to evolve about 1.5 billion years ago (Lehninger et al., 1993) they went through innumerable changes in structures and processes to enable them to survive in relatively dry environments. As a result, single genes that substantially altered plants' capacity to survive dry circumstances during the first steps of land colonization became difficult

\footnotetext{
${ }^{1}$ Accepted for publication on February 4, 2000.

${ }^{2}$ Agronomist, Ph.D., Embrapa-Centro Nacional de Pesquisa de Soja (CNPSo), Caixa Postal 231, CEP 86001-970 Londrina, PR. E-mail: anepo@enpso.embrapa.br, norman@cnpso.embrapa.br, jrenato@cnpso.embrapa.br

${ }^{3}$ Molecular Biologist, Ph.D., Agronomy Department, University of Arkansas, Plant Science Building, room 123, Fayetteville, AR, 72701 USA.
}

to find (Boyer, 1996) or even might have disappeared. Over time evolutionary pressure turned plant responses to stress into a complex web of responses beginning with stress perception, which initiates signal transduction pathways, and ending in changes at many metabolic, physiological and developmental levels. Therefore, responses to drought will be conditioned not only by the nature and intensity of the environmental factors involved,

E-mail: jstewart@comp.uark.edu

${ }^{4}$ Plant Physiologist, Ph.D., University of Arkansas.

E-mail: oosterhu@comp.uark.edu

${ }^{5}$ Molecular Biologist, Ph.D., United States Department of Agriculture (USDA), Agricultural Research Service (ARS), Exp. Station \& Lee Roads, Five store building, P.O. Box 345, Stoneville, MS 38776. E-mail: rturley@ag.gov 
but also by the ecological histories of species, ecotypes, cultivars and genotypes. As a result, there is a large range of molecular, biochemical and physiological responses that plants commonly present when submitted to periods of water deficit. Because several genes are likely to be involved in each trait for drought tolerance, molecular biology and plant physiology together can aid in identifying and selecting these genes, determining their influence in yield (Turner, 1997). Differentially expressed genes are usually identified by comparing mRNA abundance (Wan et al., 1996). Therefore, a partial understanding of these developmental events may be obtained by analyzing and comparing mRNAs isolated from well-watered and water-stressed plants.

Differential Display (Liang \& Pardee, 1992) is a technique that uses sub-populations of the total mRNA pool as template for representative cDNA synthesis by reverse transcription. The cDNA subpopulations are then PCR amplified resulting in the generation of a PCR profile representative of the mRNAs contained within each population. PCR products are then displayed side-by-side on polyacrylamide gels to identify treatment-specific expression (Liang \& Pardee, 1992, 1995). The Differential Display has advantage over other techniques (e.g. subtractive hybridization) because it requires only very small amounts of RNA for analysis, it is not limited by redundancy of highly expressed mRNAs or under-representation of rare mRNAs, and it has rapid output (Wilkinson et al., 1995; Wan et al., 1996).

Water deficit in plants elicits a complex of responses beginning with stress perception, which initiates a signal transduction pathway manifested in changes at many physiological/metabolic levels (Bray, 1993). The change in cell volume that accompanies drought may trigger stretch-activated channels, alter the conformation or juxtaposition of critical sensory proteins or cause alterations in the cell wall-plasmalemma continuum, thereby activating signal transduction pathways that elicit gene expression (Hare et al., 1996; Shinozaki \& YamaguchiShinozaki, 1996, 1997). As water is lost from the cell, regulatory processes are initiated that adjust the cellular metabolism to the new cellular conditions. Simultaneously, growth inhibition and alterations of developmental pathways will result in other changes in gene expression (Bohnert et al., 1995). Many waterdeficit-induced genes encode proteins predicted to protect cellular structures and functions from the effects of water loss (Bray, 1993, 1997; Boyer, 1996; Shen et al., 1997). Genes that function during changes in metabolism, regulation, signaling, and recognition of stress are also expected to be induced, but fewer of these classes of genes have been identified. Waterdeficit-induced genes will promote cellular tolerance of dehydration, protective functions in the cytoplasm, alterations of cellular osmotic potential to increase water uptake, control of ion accumulation and further gene expression regulation (Bray, 1993, 1997). Some of these predictions are derived from the deduced amino sequence and expression characteristics. However, expression of genes during stress does not guarantee that a gene product promotes the ability of the plant to survive stress (Baker et al., 1988; Bray 1993). The expression of some genes may result from injury or damage that occurred during stress. Other genes may be induced, but their expression may not alter stress tolerance. Nonetheless, some genes are required for stress tolerance and the accumulation of these gene products may become an adaptive response (Bray, 1993, 1997).

Water deficit is a major concern in cotton production. The unique expression of genes in stress tolerant cotton genotypes could be used to study drought tolerance mechanisms and to identify other genotypes with similar characteristics. Identifying and understanding mechanisms of water stress tolerance is crucial to the development of new tolerant cultivars not only in cotton, but also in other species.

The objective of this study was to identify and isolate genes that are differentialy expressed in four selected cotton genotypes contrasting according to their tolerance to water deficit.

\section{MATERIAL AND METHODS}

Genotypes and greenhouse conditions

Seeds of two water-deficit sensitive (Stoneville 506 and CS 50) and two water-deficit tolerant (Siokra L-23 and 
T-1521) cotton (Gossypium hirsutum L.) genotypes (Wullschleger \& Oosterhuis, 1991; Nepomuceno et al., $1996,1998)$ were germinated in pots containing washed sand and grown under greenhouse conditions. Temperatures in the greenhouse were $30^{\circ} \mathrm{C} \pm 2^{\circ} \mathrm{C}$ during day and $25^{\circ} \mathrm{C} \pm 2^{\circ} \mathrm{C}$ at night with relative humidity near $50 \%$. Metal halide illumination lamps (1,000 watts) were used to supplement natural radiation. Light radiation reached a maximum of $1,500 \mu \mathrm{mol} \mathrm{m}^{-2} \mathrm{~s}^{-1}$ at the top of canopy at midday.

\section{Irrigation and water-deficit induction}

Irrigation was conducted using balanced nutrient solution at $\mathrm{pH} 6.6$ containing $98 \mathrm{mg} \mathrm{L}^{-1} \mathrm{NO}_{3}^{-}, 14 \mathrm{mg} \mathrm{L}^{-1} \mathrm{NH}_{4}^{+}$, $117 \mathrm{mg} \mathrm{L}^{-1} \mathrm{~K}, 80 \mathrm{mg} \mathrm{L}^{-1} \mathrm{Ca}, 31 \mathrm{mg} \mathrm{L}^{-1} \mathrm{P}, 32 \mathrm{mg} \mathrm{L}^{-1} \mathrm{~S}$, $24 \mathrm{mg} \mathrm{L}^{-1} \mathrm{Mg}, 0.02 \mathrm{mg} \mathrm{L}^{-1} \mathrm{Mo}, 0.1 \mathrm{mg} \mathrm{L}^{-1} \mathrm{Mn}, 0.13 \mathrm{mg} \mathrm{L}^{-1}$ $\mathrm{Cl}, 0.01 \mathrm{mg} \mathrm{L}^{-1} \mathrm{Cu}, 0.25 \mathrm{mg} \mathrm{L}^{-1} \mathrm{~B}$ and $0.025 \mathrm{mg} \mathrm{L}^{-1} \mathrm{Zn}$ (Henvitt, 1963). The volume of nutrient solution added periodically was calculated to maintain the pots of the stressed treatments at $5 \%$ gravimetric humidity $(\mathrm{GH})$ and non-stressed treatments at $15 \% \mathrm{GH}$. Gravimetric humidity percentage give the amount (weight) of water present in relation to the sand. Percentages are based on the sand dry weight. These percentages were chosen based on preliminary experiments where $5 \% \mathrm{GH}$ was found to promote a mild water deficit and $15 \%$ GH kept treatments near field capacity. All treatments were kept at 15\% GH until 20 days after germination, after which irrigation was withheld from the stressed treatments until sand humidity reached 5\% GH, which required approximately 48 hours Pots were weighted twice a day (early in the morning and late afternoon) and nutrient solution volume was added to keep treatments at the desired values of GH. Twice a week plants from reserve pots receiving the same treatments of the experimental pots were harvested and their weight discounted to keep the treatment pots at desired values.

\section{RNA extraction}

At the $6^{\text {th }}$ day (after stressed treatments reached 5\% $\mathrm{GH})$ leaves of the four cotton genotypes were collected for RNA isolation. The timing for sampling was decided based in previous work (Nepomuceno et al., 1998) showing that tolerant/sensitive cotton genotypes, used in this work, reached higher differences in water and osmotic potential after six days of water deficit. The fourth leaf from the apex was sampled to obtain a $4 \mathrm{~g}$ leaf sample. If a $4 \mathrm{~g}$ sample was not provided with only the fourth leaf, the third and fifth leaves were also used. Immediately after sampling, leaf tissues were rapidly and carefully washed in distilled water, blotted, and stored at $-80^{\circ} \mathrm{C}$. A modified combination of the Wan \& Wilkins (1994) and Holt (1995) hot borate extraction protocol was used for RNA isolation and quantification. Subsequent purification was accomplished with a modified procedure according to Song et al. (1995).

\section{Reverse transcription}

Before the reverse transcription (RT) reaction $2 \mu \mathrm{g}$ of purified total RNA was mixed in a $200 \mu \mathrm{L}$ tube with $10 \mu \mathrm{L}$ of $5 \mathrm{x}$ M-MLV RT buffer, $1.24 \mu \mathrm{L}$ of $10 \mathrm{mM}$ dNTP, $2.42 \mu \mathrm{L}$ anchor primer $(50 \mu \mathrm{M}), 1 \mu \mathrm{L}$ RNasin (Promega, Madison, WI), and DEPC treated water to a total volume of $50 \mu \mathrm{L}$. The reaction mix was heated at $65^{\circ} \mathrm{C}$ for five minutes after which $1.5 \mu \mathrm{L}$ of Moloney Murine Leukemia Virus (M-MLV) Reverse Transcriptase (Promega,

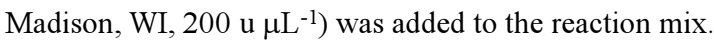
After one hour at $37^{\circ} \mathrm{C}$ the reaction mix was heated to $99^{\circ} \mathrm{C}$ for five minutes to inactivate the reverse transcriptase. Temperature changes were performed in a thermal cycler (Hybaid OMN-E, model P-5000-HL).

\section{Polymerase chain reaction (PCR)}

Five $\mu \mathrm{L}$ of the reverse transcription reaction (that produced the cDNA:mRNA hybrids) was mixed in a $200 \mu \mathrm{L}$ tube with $5 \mu \mathrm{L}$ dNTP $(100 \mu \mathrm{M}$, Life Technologies, Grand Island, NY), $2.5 \mu \mathrm{L}$ 10x Taq buffer, $2.5 \mu \mathrm{L} \mathrm{MgCl}_{2}$ $(25 \mathrm{mM}), 0.5 \mu \mathrm{L} 10$-mer primer $(50 \mu \mathrm{M}), 1 \mu \mathrm{L}$ anchor primer $(50 \mu \mathrm{M}), 0.5 \mu \mathrm{L}^{35} \mathrm{~S}$-dATP $\left(1,250 \mathrm{Ci} / \mathrm{mmol}^{-1}\right.$, Amersham, Arlington Heights, $\mathrm{IL}), 0.5 \mu \mathrm{L}$ Taq polymerase ( $5 \mathrm{u} \mu \mathrm{L}^{-1}$, Promega, Madison, WI) and DEPC treated water to make a final volume of $25 \mu \mathrm{L}$. PCR cycling conditions were: $94^{\circ} \mathrm{C}$ for two minutes initially, and then repeated cycles of $94^{\circ} \mathrm{C}$ for 30 seconds, $42^{\circ} \mathrm{C}$ for one minute, $72^{\circ} \mathrm{C}$ for 30 seconds, for 40 cycles, followed by five minutes final extension at $72^{\circ} \mathrm{C}$ (Song et al., 1995).

Primers were obtained (Gibco BRL, Life Technologies, Grand Island, NY) at basic concentrations of 50 nmoles. Seven anchor primers $\left(\mathrm{A} 1-5^{\prime}(\mathrm{T})_{9} \mathrm{AA}^{3^{\prime}} ; \mathrm{A} 2-5^{\prime}(\mathrm{T})_{9} \mathrm{AC}^{3^{\prime}}\right.$; $\mathrm{A} 3-5^{\prime}(\mathrm{T})_{9} \mathrm{CA}^{3^{\prime}} ; \mathrm{A} 5-5^{\prime}(\mathrm{T})_{9} \mathrm{GC}^{3} ; \mathrm{A} 8-5^{\prime}(\mathrm{T})_{9} \mathrm{CG}^{3}$; $\left.\mathrm{A} 11-5^{\prime}(\mathrm{T})_{9} \mathrm{GG}^{3^{\prime}} ; \mathrm{A} 12-5^{\prime}(\mathrm{T})_{9} \mathrm{CC}^{3^{\prime}}\right)$ and eight ten-mers (B1 - 5'GAGCTTGAAC ${ }^{3}$; B3 - 5'CTGATCCATG ${ }^{3}$; B5 - 5'TAGAGCGATC ${ }^{3}$; B7 - 5'ATCTCGCTAG ${ }^{3}$; B9 - 5'GAATTTCCCC ${ }^{3}$; B11 - 5'AGGGATCTCC ${ }^{3}$; B13 - 5'AAGCTGCGAG 3'; B15 - 5'GTGCGTCCTC ${ }^{3}$ ') were used to screen the mRNA populations. 
Gel electrophoresis, autoradiography and band extraction

PCR products were separated by electrophoresis on a $6 \%$ denaturing polyacrylamide DNA sequencing gels. Gel preparation, sample loading and electrophoresis were prepared according to Sambrook et al. (1989). Ten $\mu \mathrm{L}$ of PCR product was mixed with $2 \mu \mathrm{L}$ gel loading dye. Before loading, samples were heated at $75^{\circ} \mathrm{C}$ for three minutes Electrophoresis was conducted at 70 watts for four hours. Gels were then vacuum dried on filter paper at $80{ }^{\circ} \mathrm{C}$ for 1.5 hours.

After two to three days of autoradiography, bands were analyzed and compared between water-deficit stressed and non-stressed treatments in the four cotton genotypes Differentially displayed (DD) bands were then identified and extracted from the gels. The extraction and purification of DNA from the gel slice was conducted according to Ausubel et al. (1995). After extraction and purification the band was reamplified using $10 \mu \mathrm{L}$ of the supernatant extract in a PCR reaction with the same primers and PCR conditions (except for ${ }^{35} \mathrm{~S}-\mathrm{dATP}$ ) used during the DD The reamplification reaction was then checked in a $2 \%$ NuSieve GTG (1x TBE buffer) agarose mini-gel.

\section{Cloning and sequencing}

PCR reamplifications yielding only one band were purified (using a commercial purification system; Wizard PCR purification system, Promega, Madison, WI) and cloned in pGEM-T vectors according to manufactures instructions (Promega, Madison, WI). The concentrations of PCR product and vector were measured in a Hoefer fluorometer (TKO 100) and mixed in a molar ratio of $6: 1$ (insert:vector). After ligation, the pGEM-T vectors with the inserts were used to transform Escherichia coli (JM 109 strain). E. coli competent cells were prepared according to Sambrook et al. (1989). After transformation and plating, E. coli cells were incubated overnight at $37^{\circ} \mathrm{C}$ Eight white colonies were then selected and spread on LB plates (with IPTG/X-Gal/ampicillin) and incubated overnight $\left(37^{\circ} \mathrm{C}\right)$ to confirm the absence of $\beta$-galactosidase activity. White colonies have the lacZ gene inactivated due to insertion of the reamplified cDNA fragment. Restriction of plasmidial DNA extracted from putative recombinants confirmed the cloning of fragments inserted between recognition sites for restriction enzymes in the pGEM-T vector. Plasmidial DNA was extracted using Wizard Plus midipreps (Promega, Madison, WI). After restriction, a DNA fragment with approximately the same size as the fragment that was used in the ligation reaction should be present when visualized in a $2 \%$ agarose gel.
After confirmation that the right fragments were inserted, cycle sequencing of the inserted fragments was conducted in a ALFTM DNA automatic sequencer (Pharmacia Biotech). The reactions were performed using the ALFexpress AutoCycle sequencing kit (Pharmacia Biotech). Database search for homology was carried out using the BLASTN2 and BLASTX2 (Altschul et al., 1990) programs provided by Bork Group's Advanced Search Services at EMBL

\section{Ribonuclease protection assay}

Anti-sense RNA probes ( ${ }^{32} \mathrm{P}$ labeled, Amersham, Arlington Heights, IL) complementary to part of the target RNA to be analyzed were synthesized from the fragments cloned into the pGEM vector. Complete runoffs of the transcripts representing the insert anti-sense strand were produced using T7 or SP6 RNA polymerase. The antisense riboprobes were produced using a MAXIscrip ${ }^{\mathrm{TM}}$ kit (Ambion, Austin, TX, USA) according to manufacturer instructions. The RPA reactions were performed using a HybSpeed $^{\mathrm{TM}} \mathrm{RPA}^{\mathrm{TM}}$ kit (Ambion, Austin, TX, USA). Labeled anti-sense riboprobes that hybridized to complementary RNA in the mixture (which contains the original total RNA extract) were protected from ribonuclease digestion, and were then separated on a $5 \%$ polyacrylamide gel and visualized by autoradiography. A positive control for hybridization ( $\beta$ - actin mRNA in total RNA isolated from mouse liver) and positive and negative controls (Yeast RNA) to check for RNase digestion and probe hybridization were also loaded in the polyacrylamide gel. Messenger RNA from one of the sensitive genotypes (CS 50) submitted and not submitted to water deficit was also used in the RPA analysis to check for expression.

\section{RESULTS AND DISCUSSION}

A specific physiological response to water deficit, in reality, represents a combination of previous molecular events activated by the stress signal which triggers water-stress specific transcription. Qualitative or quantitative differences in gene expression during drought must be present in genotypes that differ in tolerance to water-deficit stress (Bray, 1993). However, to identify these genotypes physiological characterization is essential. Previous work (Nepomuceno et al., 1998) showed that cotton genotypes Siokra L-23 and $\mathrm{T}-1521$ partially tolerate water deficit stress, whereas 
genotypes CS 50 and Stoneville 506 show sensitivity. Siokra L-23 and T-1521 exhibited a significant osmotic adjustment in their leaves what kept water potential near control values during the water deficit stress. In the present work the same sensitive and tolerant cotton genotypes studied by Nepomuceno et al. (1998) were analyzed for gene expression during water deficit. Fifty-two cDNA fragments originated from mRNA transcripts differentially expressed during water deficit were identified, isolated from the polyacrylamide gels, cloned in pGEM-T vectors, and sequenced. Search in gene banks showed that one of these fragments, a 324 bp cDNA designated A12B15-5 (band A in Fig. 1; GenBank Accession \# AF056944), is highly homologous (1.7e-52 P(N)) to a $\mathrm{NADP}(\mathrm{H})$ oxidase (rbohA gene) found in Oryza sativa (Groom et al., 1996) both at DNA level (65-74\%) and amino acid sequence level (75\%) (Figs. 2 and 3 ). This cloned transcript was up regulated only during the water-deficit stress and only in Siokra L-23 (Fig. 1), a drought tolerant genotype according to Wullschleger \& Oosterhuis (1991) and Nepomuceno et al. (1996, 1998). Torres et al. (1998) also identified two homologous of this gene in Arabidopsis thaliana that were up regulated during infection with fungi and bacteria. The amino acid sequences of these two homologous (E and F; A. thaliana), the rbohA gene (O. sativa) and the consensus regions were compared with cDNA clone A12B15-5, showing, respectively, $64 \%, 80 \%, 75 \%$ and $75 \%$ homology (Fig. 3). A 75-aminoacid deletion can be observed in clone A12B15-5 in this comparison, what could suggest that this enzyme region may not be essential for activity.

During cell dehydration due to water deficit or other causes (e.g., salinity, cold stress), turgor pressure at the cellular level is altered (Wullschleger \& Oosterhuis, 1991; Delauney \& Verma, 1993). A change in the osmotic potential across a plasma membrane, caused by the decrease in turgor pressure, might be a major trigger of the water stress response at the molecular level (Yahraus et al., 1995; Shinozaki \& Yamaguchi-Shinozaki, 1996, 1997). Osmosensors and membrane protein changes due to modifications in cell wall/cell membrane stability may activate expression of genes like $\operatorname{NADP}(\mathrm{H})$ oxidases. High concentrations of $\mathrm{O}_{2}$ leaking through

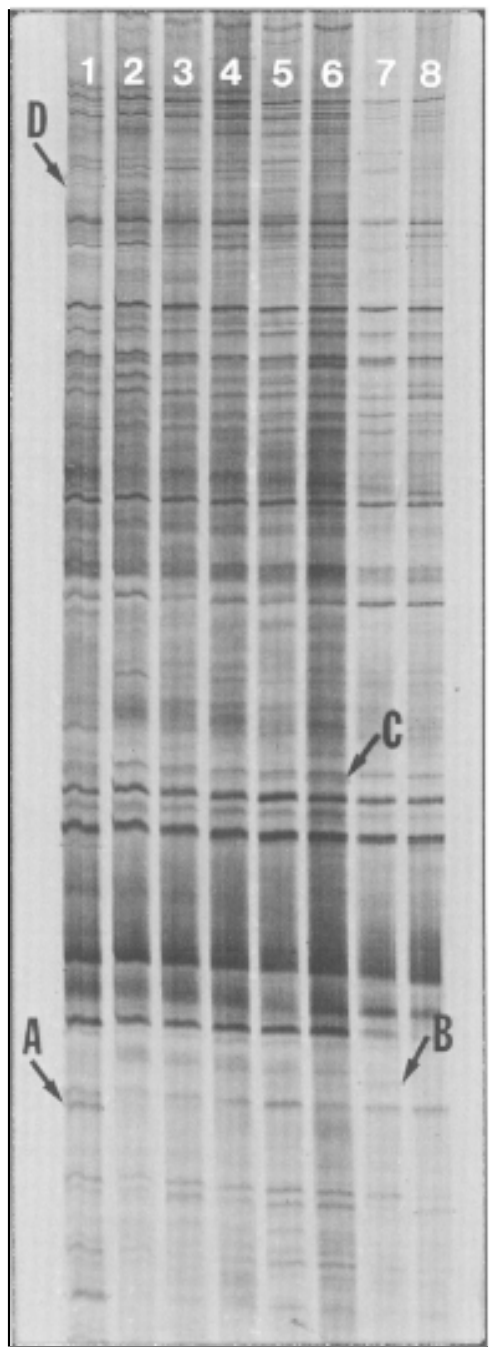

FIG. 1. Differential display (DDRT-PCR) of four cotton genotypes after periods of water deficit. Lane: 1- Siokra L-23, stressed; 2-Siokra L-23, non-stressed; 3- CS-50, stressed; 4-CS-50, non-stressed; 5- Stoneville 506, stressed; 6- Stoneville 506, non-stressed; 7- T-1521, stressed; 8- T-1521, non-stressed. $R T$-PCR reactions were conducted using anchor primer A12-5' $(T)_{9} C C^{3^{\prime}}$ and 10-mer B15- 'GTGCGTCCTC ${ }^{3}$. cDNA fragments, which appear to be differentially expressed, are indicated by arrows and letters (A - A12B15-5; B - A12B15-6; C - A12B15-8; D - A12B15-13). 


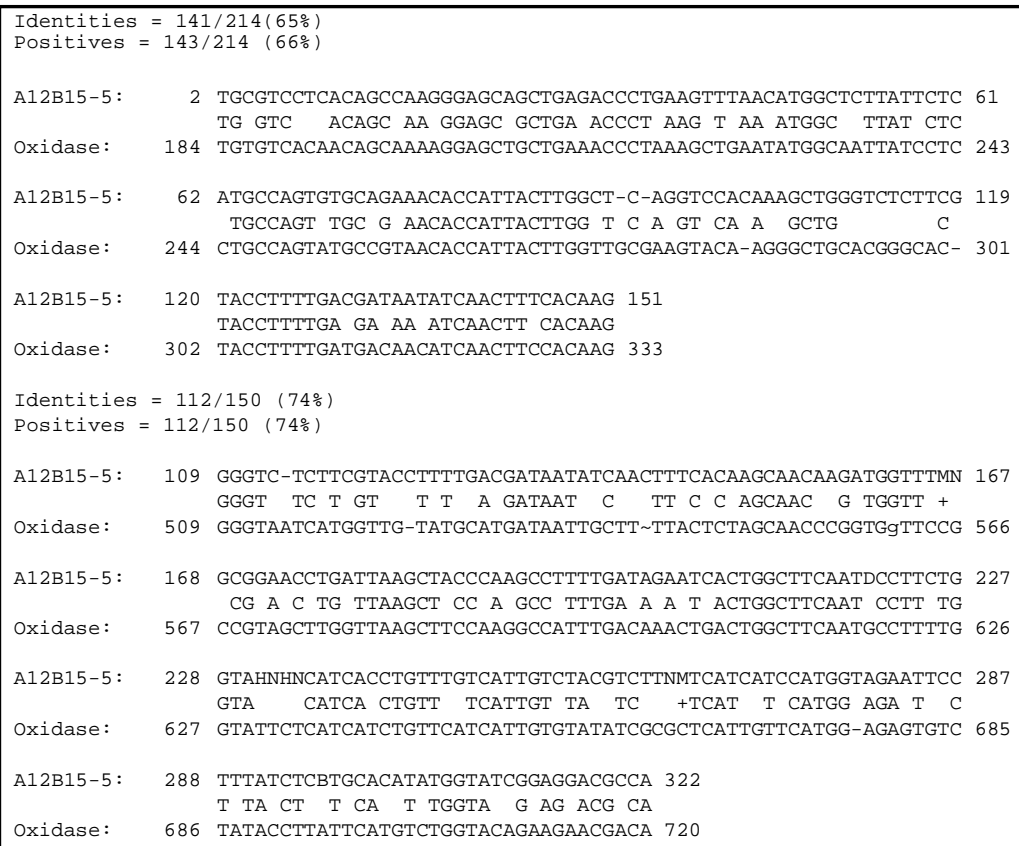

FIG. 2. BLAST search result comparing nucleotide sequence of clone A12B15-5 with rbohA Oryza sativa mRNA for NAD(P)H oxidase.

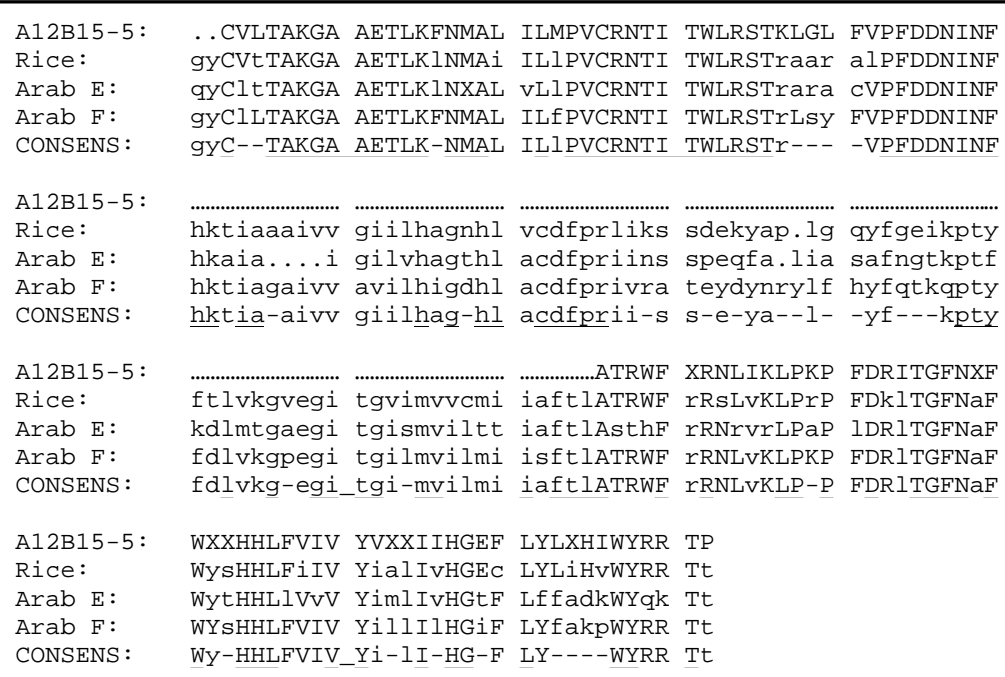

FIG. 3. Amino acid sequence homology among clone A12B15-5, three homologous and the consensus region of $\mathrm{NAD}(\mathrm{P}) \mathrm{H}$ oxidase. Identities with: Arabidopsis thaliana (homolog E) $=64 \%$, Arabidopsis thaliana $($ homolog F $)=80 \%$, Oryza sativa $=75 \%$, Consensus $=75 \%$. The A15B15-5 aa sequence has a 75 aa (225 nucleotides) deletion relative to the other homologous. the cell wall/cell membrane may also be one of the first signals showing that something is compromising cell integrity. Activated $\operatorname{NADP}(\mathrm{H})$ oxidases use $\mathrm{O}_{2}$ as substrate, altering concentration of reactive oxygen species like superoxide anion $\left(\mathrm{O}_{2}-\right)$, hydroperoxyl radical $\left(\mathrm{HO}_{2}{ }^{\circ}\right)$ and hydrogen peroxide $\left(\mathrm{H}_{2} \mathrm{O}_{2}\right)$. Many roles for these reactive oxygen species have been proposed. Initially, oxygen radicals were believed to function only in the destruction of microbes, and in blocking the spread of infection by causing Hypersensitive Response (HR) (Peng \& Kuc, 1992). However, production of reactive oxygen radicals has been showed to be a common feature during many kinds of stress (Yahraus et al., 1995), suggesting that a common oxidative burst occurs during stress situations, probably as general response involved in triggering signal transduction cascades (Degousée et al., 1994; Levine et al., 1994; Baker \& Orlandi, 1995; Low \& Merida, 1995). This common mechanism could explain the presence of homologous $\mathrm{NAD}(\mathrm{P}) \mathrm{H}$ oxidases expressed in different species like A. thaliana and $O$. sativa. However, this specific allele found in cotton seemed to be uniquely expressed in Siokra L-23, and only during water deficit (Figs. 1 and 4). Consequently, it might 


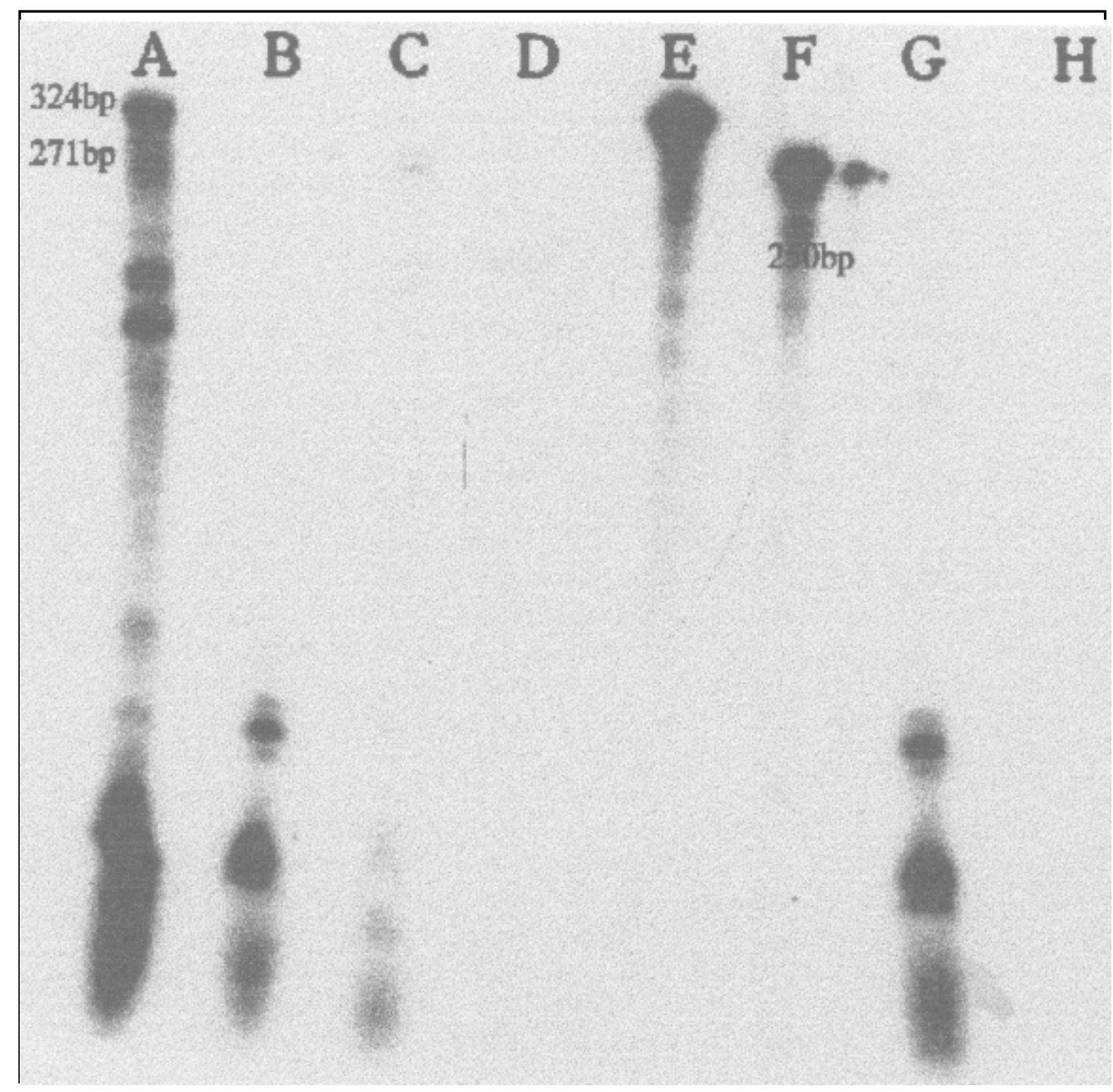

FIG. 4. Ribonuclease protection assay of clones A12B15-5 and A12B15-6. Lane: A - A12B15-5, Siokra L-23, water-stressed (324 bp); B - A12B15-5, Siokra L-23, non-stressed; C - A12B15-6, T-1521, waterstressed (271 bp); D - A12B15-6, T-1521, non-stressed; E - Yeast RNA not RNase digested; F - $\beta$-actin positive control (250 bp); G - A12B15-5, CS-50, water-stressed; H - Yeast RNA RNase digested and hybridized with anti-sense probes A12B15-5 and A12B15-6.

contribute to the stress tolerance of this genotype. The magnitude and type of signals perceived by neighboring cells depend on the relative rates of signal production, diffusion, and reactivity toward macromolecules (Hammond-Kosack \& Jones, 1996). Thus, a signal more sensitive $\mathrm{NAD}(\mathrm{P}) \mathrm{H}$ oxidase may trigger faster and earlier defense responses to minimize the damage due to dehydration and permit 
sustained metabolic activity compared with sensitive genotypes. Mutations in genes conditioning the signal pathways for the activation of cellular defense genes could account for a genotype, more waterdeficit tolerant then another. The DD gel (Fig. 1) and the RPA analysis (Fig. 4) indicate the differential expression of clone A12B15-5 in Siokra L-23 only during water deficit. Artifacts in PCR reactions some times produce differentially displayed bands that were not generated from a mRNA transcript. Thus, ribonuclease protection assay (RPA) was used to search for false positives.

The up regulation during water deficit of this Siokra L-23 NAD(P)H oxidase, might be analogous to mechanisms observed in other species like $E$. coli. In this bacteria the EnvZ protein, a two-component Histidine kinase, functions as an osmosensor and monitors mechanical changes of the cell membrane during osmotic stress (Wurgler-Murphy \& Saito, 1997). EnvZ is activated by autophosphorylation at a Histidine residue under hyperosmotic conditions and then phosphorylates an Asp residue of the OmpR protein. Phosphorylated OmpR functions as a transcription factor to up-regulate the OmpC gene and down-regulate the $\mathrm{OmpF}$ gene. Both genes encode proteins of the bacterial outer membrane, and together these proteins regulate turgor pressure (Shinozaki \& Yamaguchi-Shinozaki, 1996, 1997). The perception that the cell is loosing water may occur in a similar way in plants. Thus, activation of defense genes and the defense response should be directly dependent on the efficiency of signal transduction cascades.

Generation of reactive oxygen radicals likely changes the redox balance in the cell (Shinozaki \& Yamaguchi-Shinozaki, 1997). In mammals, Schreck et al. (1991) and Meyer et al. (1993) showed that many transcription factors are redox regulated. In plants, redox balance also seems to regulate the stability of specific defense-related mRNA transcripts (Mehdy, 1994). The shift in the oxidative/reductive environment of the cell following stress-induced accumulation of reactive oxygen intermediates appear to trigger several stress responses at the cellular level (Chapin, 1991; Shinozaki \& Yamaguchi-Shinozaki, 1997), but they also are very dangerous to many cell components (Hammond-Kosack \& Jones, 1996;
Hare et al., 1996). Therefore, the significant osmotic adjustment observed in Siokra L-23 could be related to accumulation of these oxygen species and osmolytes that play a role as radical scavengers (Bohnert \& Jensen, 1996; Zhu et al., 1997) or in water retention (Bray, 1993; Zhu et al., 1997).

During water deficit Siokra L-23 showed and sustained only a small reduction in photosynthetic rate (Nepomuceno et al., 1998). Genty \& Silva (1987) observed reduction in photosynthetic rates in cotton plants due to impairment of electron flow and indirect inhibition due to lack of utilization of reducing power during water stress. Siokra L-23 may be able to keep photosynthesis high during stress due to the presence of a redox protection mechanism that helps maintain photosynthetic metabolic function. Thus, a precise spatial and temporal, qualitative and quantitative coordination of induced defenses is crucial in genotypes with higher water-deficit tolerance. The oxidative burst characteristic of stressed tissues should be considered a general response to cell wall/cell membrane integrity. Microbe resistance, water-deficit tolerance, cold stress tolerance, all seem to be just the final result of a cascade of molecular events where the efficiency in perception and transmission of the stress signal is essential in expressing higher or lower resistance/ tolerance.

Using only yield to select plants for water stress tolerance introduces a bias where the environment assumes a huge significance. The major contribution of identifying differentially displayed genes is that they can be used to elaborate hypotheses about how plants respond to drought. Identification of differentially expressed sequence tags (EST) during stress situations is contributing to understand the puzzle of how plants control their tolerance or sensitivity. Integrated genetic, physiological, biochemical, and molecular analysis will eventually provide insights into the cellular processes that are critical for water stress tolerance. By knowing the role of these genes we increase the understanding and the potential to use these genes to select and/or to create new genotypes expressing higher waterdeficit tolerance to maintain substantial yield. 
Association of plant physiology and molecular biology techniques should favor a better understanding of how plants respond to water deficit since tolerance to drought in plants results from complex series of metabolic mechanisms working isolated or in combination.

\section{CONCLUSIONS}

1. The up regulated $\mathrm{NADP}(\mathrm{H})$ homologue $\mathrm{CDNA}$ identified in this work might be involved in the higher drought tolerance identified in Siokra L-23.

2. The high level of homology of this $\operatorname{NADP}(\mathrm{H})$ oxidase expressed during drought in cotton with $\mathrm{NADP}(\mathrm{H})$ oxidases up regulated in Oryza sativa and Arabidopsis thaliana during fungi and bacterial infection suggests a common pathway for stress responses where the cell wall/cell membrane integrity may play a key role.

\section{REFERENCES}

ALTSCHUL, S.F.; GISH,W.; MILLER, W.; MYERS, E.W.; LIPMAN, D.L. Basic local alignment search tool. Journal of Molecular Biology, London, v.215, p.403-410, 1990.

AUSUBEL, F.; BRENT, R.; KINGSTON, R.E.; MOORE, D.D.; SEIDMAN, J.G.; SMITH, A.J.; STRUHL, $\mathrm{K}$. Short protocols in molecular biology. New York : J. Wiley, 1995. 809p.

BAKER, J.; ORLANDI, E.W. Active oxygen in plant pathogenesis. Annual Review of Phytopathology, Palo Alto, v.33, p.299-321, 1995.

BAKER, J.; STEELE, C.; DURE, L. Sequence and characterization of 6 Lea proteins and their genes from cotton. Plant Molecular Biology, Dordrecht, v.11, p.277-291, 1988.

BOHNERT, H.J.; JENSEN, R.G. Strategies for engineering water-stress tolerance in plants. Trends in Biotechnology, Oxford, v.14, p.89-97, 1996.

BOHNERT, H.J.; NELSON, D.E.; JENSEN, R.G Adaptations to environmental stresses. Plant Cell, Rockville, v.7, p.1099-1111, 1995
BOYER, J.S. Advances in drought tolerance in plants. Advances in Agronomy, San Diego, v.56, p.187218,1996

BRAY, E.A. Molecular responses to water deficit. Plant Physiology, Rockville, v.103, p.1035-1040, 1993.

BRAY, E.A. Plant responses to water deficit. Trends in Plant Science, Oxford, v.2, p.48-54, 1997.

CHAPIN, F.S. Integrated responses of plants to stress: a centralized system of physiological responses. BioScience, Washington, v.41, p.29-36, 1991.

DEGOUSÉE, N.; TRIANTAPHYLIDES, C.; MONTILLET, J.L. Involvement of oxidative processes in the signaling mechanisms leading to the activation of glyceollin synthesis in soybean (Glycine max). Plant Physiology, Rockville, v.104, p.945952,1994

DELAUNEY, A.; VERMA, D. Proline biosynthesis and osmoregulation in plants. Plant Journal, Oxford, v.4, p.215-223, 1993.

GENTY, B.; SILVA, J.B.V. da. Effects of drought on primary photosynthetic processes of cotton leaves. Plant Physiology, Rockville, v.83, p.360-364, 1987.

GROOM, Q.J.; TORRES, M.A.; FORDHAMSKELTON, A.P.; HAMMOND-KOSACK, K.; ROBINSON, N.J.; JONES, J. RbohA: a rice homologue of the mammalian gp91 phox respiratory burst oxidase gene. Plant Journal, Oxford, v.10, p.515522,1996

HAMMOND-KOSACK, K.E.; JONES, J. Resistance gene-dependent plant defense responses. Plant Cell, Rockville, v.8, p.1773-1791, 1996.

HARE, P.; PLESSIS, S.P.; CRESS, W.; STADEN, J.V. Stress-induced changes in plant gene expression. South African Journal of Science, Pretoria, v.92, p.431-439, 1996.

HENVITT, E.J. Mineral nutrition of plants in culture media. In: STEWART, F.C. (Ed.). Plant physiology. New York : Academic, 1963. p.97-134.

HOLT, S.W. A hierarchical evaluation of selected growth phenomena in reproductive structures of Gossypium hirsutum L. Fayetteville : University of Arkansas, 1995. 201p. Ph.D. Thesis.

LEHNINGER,A.L.; NELSON, D.L.; COX, M.M. Cell. In LEHNINGER, A.L.; NELSON, D.L.; COX, M.M. (Ed.). Principles of biochemistry. New York : Worth, 1993. p.21-55. 
LEVINE, A.; TENHAKEN, R.; DIXON, R.; LAMB, C $\mathrm{H}_{2} \mathrm{O}_{2}$ from the oxidative burst orchestrates the plant hypersensitive disease resistance response. Cell, Cambridge, United States, v.79, p.583-593, 1994.

LIANG, P.; PARDEE, A.B. Differential display of eukaryotic messenger RNA by means of the polymerase chain reaction. Science, Washington, v.257, p.967-971, 1992.

LIANG, P.; PARDEE,A.B. Recent advances in differential display. Current Opinion in Immunology, London, v.7, p.274-280, 1995.

LOW, P.S.; MERIDA, J.R. The oxidative burst in plant defense: function and transduction. Physiologia Plantarum, Copenhagen, v.96, p.533-542, 1995.

MEHDY, M.C. Active oxygen species in plant defense against pathogens. Plant Physiology, Rockville, v.105, p.467-472, 1994

MEYER, M.; SCHRECK, R.; BAEUERLE, P.A. $\mathrm{H}_{2} \mathrm{O}_{2}$ and antioxidants have opposite effects on activation of NF-kB and AP-1 in intact cells: AP1 as secondary antioxidant-responsive factor. European Molecular Biology Organization Journal, Oxford, v.12, p.2005-2015, 1993

NEPOMUCENO, A.L.; OOSTERHUIS, D.M.; STEWART J.M. Characterization of water deficit stress in cotton genotypes by measuring water and osmotic potential in roots and leaves. In: COTTON RESEARCH MEETING, 1996, Fayetteville. Proceedings. Fayetteville : University of Arkansas, 1996. p.96-101. (Arkansas Agricultural Experiment Station. Special Report, 178).

NEPOMUCENO, A.L.; OOSTERHUIS, D.M.; STEWART J.M. Physiological responses of cotton leaves and roots to water deficit induced by polyethylene glycol. Environmental and Experimental Botany, Botany, v.40, p.29-41, 1998

PENG, M.; KUC, J. Peroxidase-generated hydrogen peroxide as a source of antifungal activity in vitro and on tobacco leaf disks. Phytopathology, St. Paul, v.82, p.696-699, 1992.

SAMBROOK, J.; FRITSCH, E.F.; MANIATIS, T Molecular cloning: a laboratory manual. 2.ed. Cold Spring Harbor : Cold Spring Harbor Press, 1989. $2347 \mathrm{p}$

SCHRECK, R.; RIEBER, P.; BAEUERLE, P.A. Reactive oxygen intermediates as apparently widely used messengers in the activation of the NF-kB transcription factor and HIV-1. European Molecular Biology Organization Journal, Oxford, v.10, p.2247-2258, 1991.

SHEN, B.; JENSEN, R.G.; BOHNERT, H.J. Mannitol protects against oxidation by hydroxyl radicals. Plant Physiology, v.115, p.527-532, 1997.
SHINOZAKI, K.; YAMAGUCHI-SHINOZAKI, K. Gene expression and signal transduction in water stress response. Plant Physiology, Rockville, v.115, p.327-334, 1997.

SHINOZAKI, K; YAMAGUCHI-SHINOZAKI, K Molecular responses to drought and cold stress. Current Opinion in Biotechnology, London, v.7, p.161-167, 1996.

SONG, P.; YAMAMOTO, E.; ALLEN, R.D. Improved procedure for differential display of transcripts from cotton tissues. Plant Molecular Biology Reporter, Dordrecht, v.13, p.174-181, 1995.

TORRES, M.A.; ONOUCHI, H.; HAMADA, S.; MACHIDA, C.; KOSACK, K.E.H.; JONES, J.D. Six Arabidopsis thaliana homologues of the human respiratory burst oxidase (gp91 phox). Plant Journal, Oxford, v.14, n.3, p.365-370, May 1998.

TURNER, N.C. Further progress in crop water relations Advances in Agronomy, San Diego, v.58, p.293338,1997

WAN, C.; WILKINS, T.A. A modified hot borate method significantly enhances the yield of high-quality RNA from cotton (Gossypium hirsutum L.). Analytical Biochemistry, San Diego, v.223, p.1-6, 1994.

WAN, J.S.; SHARP, S.J.; POIRIER, G.M.C.; WAGAMAN, J.C.; PYATI, J.; HOM, Y.; GALINDO, J. E.; HUVAR, A.; PETERSON, P.A.; JACKSON, M.R.; ERLANDER, M.G. Cloning differentially expressed mRNAs. Nature Biotechnology, New York, v.14, p. 1685-1691, 1996.

WILKINSON, J.Q.; LANAHAN, M.B.; CONNER, T.W.; KLEE, H.J. Identification of mRNAs with enhanced expression in ripening strawberry fruit using polymerase chain reaction differential display. Plant Molecular Biology, Dordrecht, v.27, p.1097-1108, 1995.

WULlSCHLEGER, S.D.; OOSTERHUIS, D.M. Photosynthesis, transpiration, and water-useefficiency of cotton leaves and fruit. Photosynthetica, Dordrecht, v.25, p.505-515, 1991.

WURGLER-MURPHY, S.M.; SAITO, H. Two-component signal transducers and MAPK cascades. Trends in Biochemical Sciences, Oxford, v.22, p.172-176, 1997

YAHRAUS, T.; CHANDRA, S.; LEGENDRE, L.; LOW, P.S. Evidence for a mechanically induced oxidative burst. Plant Physiology, Rockville, v.109, p.12591266, 1995.

ZHU, J.; HASEGAWA, P.M.; BRESSAN, R.A. Molecular aspects of osmotic stress in plants. Critical Reviews in Plant Sciences, Boca Raton, v.16, p.253-271, 1997. 